\title{
How reminders of the 1918-19 pandemic helped Australia and New Zealand respond to COVID-19
}

\author{
Geoffrey W. Rice \\ Department of History, College of Arts, University of Canterbury, Private Bag 4800, Christchurch 8140, New Zealand \\ Corresponding author. E-mail: geoff.rice@canterbury.ac.nz
}

\begin{abstract}
This article will argue that the memory of the great 'Spanish' influenza pandemic of 1918-19 played a significant role in the preparedness and response of Australia and New Zealand to the COVID-19 pandemic, and may help to explain their success compared with Europe and North America. An obvious alternative explanation for the success of Asian states such as China, Singapore, Hong Kong, South Korea, Taiwan, and Japan would be their experience of the SARS outbreak in 2002 and the H7N9 influenza outbreak of 2013. However, this explanation does not apply to Australia or New Zealand. All of these states had pandemic plans, initially developed with encouragement from the World Health Organization after the SARS outbreak, but only Australia and New Zealand appear to have directly incorporated 'lessons' from 1918-19 into their pandemic plans.
\end{abstract}

Keywords: Australia; COVID-19; influenza pandemic; New Zealand; pandemic planning

\section{The 1918-19 influenza pandemic 'down-under'}

It has long been accepted that the so-called 'Spanish' influenza pandemic of 1918-19 was the world's worst recorded pandemic since the Black Death of the fourteenth century. ${ }^{1}$ The 1918 flu did not originate in neutral Spain, where newspapers reporting the illness of King Carlos XIII invented a nickname for the new influenza virus. ${ }^{2}$ A long-held assumption that it started in China has now been debunked. ${ }^{3}$ The best evidence for origin leads back to Haskell County, Kansas, in early 1918. ${ }^{4}$ However, recent epidemiological research has suggested that precursor strains of the virus may have been circulating for several years before $1918 . .^{5}$ Estimates of mortality have steadily increased since Edwin Jordan first suggested 21.7 million in 1927.6 Patterson and

\footnotetext{
${ }^{1}$ Recent general accounts include Laura Spinney, Pale Rider: The Spanish Flu of 1918 and How It Changed the World (New York: Hachette, 2017); Catharine Arnold, Pandemic 1918: Eyewitness Accounts (New York: St Martin's, 2018); and Jeremy Brown, Influenza (New York: Touchstone, 2018).

${ }^{2}$ Maria-Isabel Porras-Gallo and Ryan A. Davis, eds., The Spanish Influenza Pandemic of 1918-19: Perspectives from the Iberian Peninsula and the Americas (Rochester, NY: University of Rochester Press, 2014).

${ }^{3}$ G. Dennis Shanks, 'No Evidence of 1918 Influenza Pandemic Origin in Chinese Laborers/Soldiers in France', Journal of the Chinese Medical Association 79, no. 1 (2016): 46-8.

${ }^{4}$ John M. Barry, The Great Influenza (New York: Viking, 2004), 91-7.

${ }^{5}$ Donald R. Olson, Lone Simonsen, Paul J. Edelson, and Stephen S. Morse, 'Epidemiological Evidence of an Early Wave of the 1918 Influenza Pandemic in New York City', Proceedings of the National Academy of Sciences of the USA 102, no. 31 (2005): 11059-63.

${ }^{6}$ Edwin O. Jordan, Epidemic Influenza: A Survey (Chicago: American Medical Association, 1927).

( $)$ The Author(s), 2020. Published by Cambridge University Press.
} 
Pyle suggested 30 million in 1991, followed by Johnson and Mueller's 50 million in 2002. ${ }^{7}$ Murray and Lopez pushed the total to 60 million in 2006, with some journalists claiming as many as 100 million deaths. ${ }^{8}$ Peter Spreeuwenberg pulled this back to a mere 17.4 million in 2018, but his panel data modelling has been heavily criticized and is not widely accepted. ${ }^{9}$ The absence of reliable evidence for China and most of Africa has fogged the guesswork, but most scholars now accept a figure of about 50 million. ${ }^{10}$ While Australia and New Zealand contributed only a tiny part of this global death toll, their experience of the pandemic is interesting and instructive.

In 1918, on the eve of the influenza pandemic, Australia had 5.3 million inhabitants and New Zealand 1.15 million. Both countries had originated as British colonies and were then still predominantly of British stock, English, Welsh, Scots, and Irish. They were well-fed and welleducated colonial fragments of the most advanced Western society of the day, with medical and hospital systems modelled (with local modifications) on the 'Homeland', Great Britain, where most of their doctors had gained their qualifications. However, about one-third of all New Zealand doctors and nurses were serving overseas in the First World War. In 1915, Aussie and Kiwi soldiers from 'down-under' had suffered grievous losses in the disastrous Gallipoli campaign in Turkey, forging their identity as ANZAC allies. Speaking stereotypically, Australians saw New Zealanders 'as more English than the English', while New Zealanders often regarded their Australian cousins as noisy larrikins, 'more like Yankees' than themselves. This friendly transTasman rivalry has continued in various forms to the present day. ${ }^{11}$

Australia and New Zealand had contrasting experiences in the 'Spanish' influenza pandemic. Both experienced the mild global first wave later than the rest of the world, in September, with widespread flu but few deaths. New Zealand's severe second-wave pandemic started in late October and lasted through to late December 1918. It was an unprecedented public health disaster with a death toll of about 9,000 and an overall death rate of 7.8 per thousand, but this masks a sharp ethnic difference. The majority Pākehā (European) population lost 6,600 at a rate of 6.1 per thousand (similar to Canada or the USA), but the indigenous Māori population lost 2,500 from 51,000 at a rate of 49 per thousand, one of the world's highest death rates in $1918 .{ }^{12}$ Other Polynesian societies in Tahiti and Western Samoa suffered even worse rates, the latter notoriously losing one-fifth of its pre-pandemic population. ${ }^{13}$

Australia, by contrast, escaped or delayed the severe second wave thanks to a strict maritime quarantine from mid October 1918. Its 'Spanish influenza' pandemic occupied most of 1919 in the world's milder third wave. Melbourne had the first cases in January, probably from a returning troopship, but Sydney was the first city to register influenza deaths, from early March. The city

\footnotetext{
${ }^{7}$ K. David Patterson and Gerald F. Pyle, 'The Geography and Mortality of the 1918 Influenza Pandemic', Bulletin of the History of Medicine 65, no. 1 (1991): 4-21; Niall Johnson and Juergen Mueller, 'Updating the Accounts: Global Mortality of the 1918-20 “Spanish” Influenza Pandemic', Bulletin of the History of Medicine 76, no. 1 (2002): 105-15.

${ }^{8}$ Christopher Murray, Alan D. Lopez, Brian Chin, Dennis Feehan, and Kenneth H. Hill, 'Estimation of Global Pandemic Influenza Mortality on the Basis of Vital Registration Data from the 1918-20 Pandemic: A Quantitative Analysis', Lancet 368, no. 9554 (2006-7): 2211-18.

${ }^{9}$ Peter Spreeuwenberg, Madelon Kroneman, and John Paget, 'Reassessing the Global Mortality Burden of the 1918 Influenza Pandemic', American Journal of Epidemiology 187, no. 12 (2018): 2561-7.

${ }^{10}$ Kirsty R. Short, Katherine Kedzierska, and Carolien E. van de Sandt, 'Back to the Future: Lessons Learned from the 1918 Influenza Pandemic', Frontiers in Cellular and Infection Microbiology 8, article 343 (2018): 1-19, is the best recent overview of the topic.

${ }^{11}$ Stuart Macintyre, A Concise History of Australia, 4th edn (Port Melbourne, Victoria: Cambridge University Press, 2016); Philippa Mein Smith, A Concise History of New Zealand, 2nd edn (Cambridge: Cambridge University Press, 2012).

${ }^{12}$ Estimates in Geoffrey W. Rice, Black November: The 1918 Influenza Pandemic in New Zealand, 2nd edn (Christchurch: Canterbury University Press, 2005), have been revised in Black Flu 1918: The Story of New Zealand's Worst Public Health Disaster (Christchurch: Canterbury University Press, 2017).

${ }^{13}$ Sandra M. Tomkins, 'The Influenza Epidemic of 1918-19 in Western Samoa', Journal of Pacific History 27, no. 2 (1992): 181-97.
} 
then experienced two distinct peaks of mortality, in April and June, with 3,500 deaths from 300,000 cases, a death rate of 1.2 per thousand. ${ }^{14}$

Australia emerged from 1919 with an estimated 15,000 dead from influenza, at one of the world's lowest death rates: 2.7 per thousand. Tasmania, which tried to isolate itself from mainland Australia, had the lowest recorded rate in the world: a mere 0.8 per thousand. Remoteness from the rest of the world had been no protection because both Australia and New Zealand were firmly linked by shipping to the British war effort, with thousands of soldiers on the move, both going to and returning from the war. ${ }^{15}$

\section{Coping with the pandemic in 1918-19}

New Zealand had no pandemic plan in 1918, apart from the emergency powers of the 1908 Public Health Act. Influenza was not even gazetted as a notifiable infectious disease until 6 November, when Auckland was fully involved with a rising death toll. The mild first wave of the pandemic had been late to reach the country, in September, causing widespread sickness but few deaths. This may have induced complacency among health officials, who were slow to recognize the more severe second wave as it emerged in late October from returning troopships. They kept insisting that it was the same 'ordinary' flu as in September. It must be remembered that the New Zealand Department of Public Health was relatively new (founded in 1900), and had been merged with the Hospitals and Charitable Aid Department in 1909, thereby diminishing its public health focus. It was chronically underfunded and, thanks to the war seriously understaffed, with most of its top officials seconded to the army. Head office was significantly depleted, with the chief health officer on leave and the acting chief health officer assisting the response in Auckland. The department was unable to exercise effective national leadership at this time. ${ }^{16}$

New Zealand's official response to the $1918 \mathrm{flu}$ was slow and cautious. It would have been easy to isolate the South Island, but by the time this was considered the severe second wave was already established in Christchurch. Auckland bore the brunt of the initial outbreak, losing 1,128 of its citizens from a population of 148,000 , a death rate of 7.6 per thousand. For two weeks, special trains took bodies from the central city to Waikumete Cemetery for burial by teams of clergy from all denominations. Volunteers were horrified to find many poor families living in slum conditions in older parts of the city. Wellington, the capital city, was handicapped by a lack of leadership for one crucial week. The port health officer died, the district health officer and half of the doctors went down with flu, and the mayor lacked legal powers to organize a relief effort. Temporary influenza wards were set up by the army in schools and church halls, but some volunteer staff had no experience of nursing pneumonia cases. In contrast, Christchurch organized early and well, despite the spread of infection from Armistice celebrations and Show Week, with no shortage of trained volunteers, and limited its death rate to nearly half that of Wellington. ${ }^{17}$

There were two official remedies prescribed in New Zealand. Inhalation of a $2 \%$ zinc sulphate atomized spray was hastily arranged with apparatus made by the railway workshops, and an official cough medicine was mass produced by pharmacists and distributed by relief depots and the Boy Scouts. The Minister of Health, George Warren Russell, took personal charge of the relief effort, belatedly sending a circular telegram on 12 November to order borough and county councils to take appropriate measures. Cities were divided into blocks, where committees of volunteers

\footnotetext{
${ }^{14}$ Kevin McCracken and Peter Curson, 'Flu Downunder: A Demographic and Geographic Analysis of the 1919 Flu Epidemic in Sydney, Australia', in The Spanish Influenza Pandemic of 1918-19: New Perspectives, ed. Howard Phillips and David Killingray (London: Routledge, 2003), 110-31.

${ }^{15}$ Peter Curson and Kevin McCracken, 'An Australian Perspective of the 1918-19 Influenza Pandemic', NSW Public Health Bulletin 17, nos. 7-8 (2006): 103-7.

${ }^{16}$ The next few paragraphs are based on Rice, Black November.

${ }^{17}$ Geoffrey W. Rice, 'Why Did Wellington Suffer Nearly Double the Death-Rate of Christchurch in the 1918 Influenza Pandemic?', 2018 Gardner Memorial Lecture (Christchurch: Canterbury History Foundation, 2018).
} 
patrolled the streets looking for the more serious cases. Commercial vans were commandeered to take these cases to hospital. Most of the $40 \%$ of the population who came down with the flu were nursed at home. There was always a desperate shortage of doctors and nurses, but doctors could do very little for acute pneumonia in 1918, apart from mustard poultices or aspirin. Alcohol was often recommended as a stimulant for convalescents, but with men out of work many homes ran short of food, and soup kitchens were set up in many towns and suburbs. While many doctors and nurses wore face masks, they were never mandated for the general public.

New Zealand towns and cities virtually closed down for about two weeks in mid November. Even the banks shut for a week. Shops, offices, and factories fell silent for lack of staff and customers. With so many people dying all at once, undertakers were overwhelmed and burials had to be arranged by local authorities. Fortunately the peak of mortality for the European population was passed on 23 November and deaths dwindled to single figures by the start of December. The economic impact was slight, because the closure had been relatively brief.

New Zealand's indigenous Māori, however, suffered much worse death rates than the European population. In 1918, 90\% of them were rural dwellers, and many remote settlements may have missed the protective effect of the mild first wave of the pandemic. Loss of land in the nineteenth century had reduced most Māori to poverty, with poor-quality housing and poor nutrition. Lack of sanitation and clean water supplies meant that typhoid was almost endemic in most settlements. Widespread tuberculosis and tobacco-smoking made Māori vulnerable to any new respiratory infection. Despite faulty census data and incomplete registration of Māori deaths, a fairly robust estimate of about 2,500 deaths has been made, with a death rate nearly eight times that of the European population. ${ }^{18}$

The 1918 flu made a deep and lasting impression in the private sphere of families who lost loved ones, but gradually faded from the public or collective memory. Most victims died from secondary pneumonic infections following influenza, and cyanosis made their bodies turn black soon after death, necessitating prompt burials. This gave the outbreak its popular name, 'the Black Flu', from analogy with the Black Death of the fourteenth century.

Australia was the world's 'lucky country' in the 'Spanish' influenza pandemic. With ample warning from reports of heavy mortality in South Africa, the Commonwealth Director of Quarantine, Dr John Cumpston, persuaded the federal government to impose a strict maritime quarantine on Australian ports from 17 October 1918. This was unpopular at the time, when Australian troops were starting to return from the First World War, but, apart from a few lapses, the restrictions proved effective until the end of December $1918 .{ }^{19}$

Unlike New Zealand, Australia produced a plan for influenza in 1918. After the alarming escalation of mortality in New Zealand, a national influenza planning conference was held in Melbourne on 26-27 November 1918, attended by state health ministers and health officials, together with representatives from the British Medical Association. It was agreed that the federal government would continue to assume responsibility for maritime and land quarantine, while the state governments arranged for emergency hospitals, ambulance services, and publicity campaigns. ${ }^{20}$

Australia even had a vaccine for influenza in 1918. Next to nothing was known about viruses in 1918 , but vaccines had proved successful against many bacterial infections since the 1890s. The newly established Commonwealth Serum Laboratory was tasked with producing a vaccine to combat the pneumonic complications of influenza. Over 3 million doses were distributed and

\footnotetext{
${ }^{18}$ Geoffrey W. Rice, 'Remembering 1918: Why Did Māori Suffer More Than Seven Times the Death Rate of Non-Māori New Zealanders in the 1918 Influenza Pandemic?', New Zealand Journal of History 53, no. 1 (2019): 90-108.

${ }^{19}$ G. Dennis Shanks, 'Australia's Experience of the 1918-19 Influenza Pandemic', occasional papers, University of Otago, 2018, https://www.otago.ac.nz/wellington/otago711857.pdf.

${ }^{20}$ Robyn Arrowsmith, A Danger Greater Than War: NSW and the 1918-19 Influenza Pandemic (Curtin, ACT: Australian Homeland Security Research Centre, 2007), 3.
} 
it was later claimed that many lives had been saved in hospitals by this vaccine. Australia also used the zinc-sulphate inhalation treatment, naming its facilities 'inhalatoriums'. ${ }^{21}$

The first case of severe influenza recorded in Sydney (21 January 1919) was that of a soldier who had travelled up from Melbourne by train. He was admitted to the Randwick Military Hospital but had already infected others, and twelve more cases were admitted by 28 January. Following its pandemic plan, the New South Wales government promptly announced the closure of all schools, bars, theatres, churches, and race courses. Face masks were made compulsory on trams and trains, and in public places. Community transmission grew steadily during February, but without any significant mortality, so the restrictions were lifted at the end of that month. With increased mixing of the population, infections soared and the first deaths occurred in late March. Restrictions were re-imposed, but the damage had been done. By then the federal government had finally closed the state borders, a month too late, and the state government of Victoria complained that infected cases had already arrived in Melbourne from New South Wales. Political squabbles continued to characterize the Australian response to the $1919 \mathrm{flu}$.

Sydney was the worst-affected Australian city, with two distinct peaks of mortality, in April and June. Morbidity was later estimated at $37 \%$ or about 300,000 cases. Sydney's final death toll was 3,500, at a rate of 1.2 per thousand. Melbourne set up a huge influenza hospital in the Exhibition Buildings with 1,500 beds, but still lost more than 2,500 to the pandemic. Adelaide and Perth, along with Brisbane, had later outbreaks with much lower death rates than Australia's two largest cities. $^{22}$

As with Māori in New Zealand, Australian Aborigines suffered far worse death rates than the European population, but historians are handicapped by lack of evidence for many settlements. There are no reliable estimates of overall Aboriginal population or influenza death rates. Queensland sources have been the most studied, and they hint at horrific death rates in small mission settlements. Euraba mission station had 54 deaths from a population of just 100, while Barambah had 87 deaths from 600 . Taroom had a population of 400 , half of whom were infected, and 31 died, at a rate of 77.5 per thousand. In the absence of any effective treatments or medicine, Aboriginal victims (like many Māori) tended to adopt a fatalistic attitude and refused any assistance. One doctor reported that they simply lost the will to live. ${ }^{23}$

\section{Reforms resulting from the 1918-19 pandemic}

In New Zealand, calls for a public inquiry into the influenza outbreak were fuelled by a widespread belief that the infection had been introduced by the passenger liner Niagara on 12 October. The ship had come from Vancouver and among the passengers were Prime Minister William Massey and his finance minister, Sir Joseph Ward. Rumours spread the idea that they had 'pulled strings' to avoid quarantine. This was not true - Massey cancelled a planned civic reception - and the first doctors to examine the flu cases on board could see no difference between them and flu cases ashore. The Niagara patients were taken into an isolation ward at Auckland Hospital. Much likelier sources of infection were the hundreds of sick and wounded soldiers who disembarked that same week from two troopships and then scattered to their homes all over the country. They had come from camps in southern England at the height of the severe second wave of the pandemic. ${ }^{24}$

The Epidemic Commission, headed by the retired judge Sir John Denniston, had no medical members. It interviewed more than 100 doctors, nurses, and civic leaders (but not a single Māori)

\footnotetext{
${ }^{21}$ National Museum Australia, 'Influenza Pandemic', 5 February 2019, https:/www.nma.gov.au/defining-moments/ resources/influenza-pandemic.

${ }^{22} \mathrm{McCracken}$ and Curson, 'Flu Downunder'.

${ }^{23}$ Gordon Briscoe, 'Queensland Aborigines and the Spanish Influenza Pandemic of 1918-19', Australian Institute of Aboriginal and Torres Strait Islander Studies research discussion paper 3/1996.

${ }^{24}$ These paragraphs are based on Rice, Black November, chap. 11.
} 
and reported in May 1919. The medical experts interviewed could not agree on the exact source of infection, and the commissioners leaned towards public opinion in assigning most of the blame to the Niagara. They were severely critical of the Health Department's woeful performance in the early phase of the outbreak, accusing its officials of complacency and delay, with lack of foresight and planning, but acknowledged the immense effort then put in to deal with the escalating crisis. The long delay until influenza was gazetted a notifiable disease on 6 November was typical of the department's 'wait and see' approach.

The commission's report was seriously deficient in many respects. It heard witnesses in the four main centres but ignored the great diversity of responses (and death rates) in regional centres and country towns. It spent a lot of time on the Niagara red herring, and largely ignored the Mãori population, while praising the work of voluntary organizations such as the Red Cross and St John Ambulance. Its main recommendations were for a complete overhaul of the Health Department and its relationship with local government, and the consolidation of existing legislation (including the hasty measures introduced during the outbreak) into a new Health Act.

The most beneficial outcome of the 1918 flu for New Zealand was its new Health Act of 1920. An independent Board of Health would now supervise the hospitals and health system. The Health Department was restructured into seven new divisions: hospitals, nursing, public hygiene, child welfare, school hygiene, dental hygiene, and Māori hygiene. Each division would have its own director and scientific staff under a director-general of health. The number of health districts was increased to eight and the number of district medical officers of health to twelve. They now assumed full responsibility for infectious diseases, with greatly increased emergency powers. ${ }^{25}$ The Health Act incorporated many of the 'lessons' learned from the $1918 \mathrm{flu}$ and gave the country a modern and flexible health system that lasted virtually unchanged until the 1980s. At the time it was widely recognized as a model of health legislation, and 'the best of its kind in the English language'. The Health Department's structure remained intact even after the 1938 Social Security Act, under which the government took a greater role in health purchasing. Head office structure remained virtually intact until the reforms of 1986.

Australia did not set up a commission to investigate the response to influenza in 1919 but it also produced a new Health Act, in 1921, which incorporated many of the pandemic's lessons. Unlike the New Zealand legislation, Australia's was mainly concerned with issues of quarantine, state borders, and keeping new infections out of the country. Dr Cumpston's central role in the planning and drafting process was recognized in his appointment as Australia's first director-general of health under the new act, a post he held until 1945. Also unlike the New Zealand legislation, Australia had its tropical territories to think about, and the diseases endemic in those latitudes. Like New Zealand, Australia looked to British models for its new health legislation, with appropriate modifications to suit local conditions. ${ }^{26}$

Australia's Department of Health from 1921 was mainly responsible for administering the Quarantine Act and the legislation relating to the sale of food and drugs across Australia as it applied in the various states of the Commonwealth. It also had control of the Commonwealth Serum Laboratories and the Australian Institute of Tropical Medicine. As well as collecting data on diseases and causes of death, it was charged with the scientific investigation of diseases most likely to affect Australians. Its central responsibility was the prevention and control of diseases and the education of the public in matters of hygiene and public health. In general, its task was to inspire and coordinate public health measures. ${ }^{27}$

\footnotetext{
${ }^{25}$ Geoffrey W. Rice, 'The Making of New Zealand's 1920 Health Act', New Zealand Journal of History 22, no. 1 (1988): 3-22.

${ }^{26}$ Michael Roe, 'The Establishment of the Australian Department of Health: Its Background and Significance', Historical Studies (Melbourne) 17 (1976): 176-92.

${ }^{27}$ Fifty Years of Health: A History of the Commonwealth Department of Health, 1921-1971 (Canberra: Department of Health, 1973), 1-40.
} 
As in New Zealand, the 1918-19 pandemic influenced town planning in Australia. The discovery of 'slums' in the older parts of the major cities came as a shock to many, and part of the response to the pandemic was a general review of housing stock and building codes. Brick terraced housing on the British model was abandoned in favour of single-storey houses and larger sections on tree-lined streets in more spacious suburbs. ${ }^{28}$

\section{Between pandemics}

The Australian and New Zealand health and hospital systems steadily developed over the next few decades, on the foundations laid in the 1920s. Both countries maintained an ethos of equal access by right to public hospitals and health care. British influence gradually gave way to greater interest in US advances in medicine, especially surgery, and numbers of medical men (they were nearly all men in those days) from 'down-under' travelled to centres of excellence such as the Mayo Clinic for postgraduate training and further experience. The Second World War saw rapid modernization of health services on both sides of the Tasman Sea, with an expansion of hospitals and the advent of penicillin as an effective antibiotic, surpassing the sulpha drugs developed in the 1930s. ${ }^{29}$

Australia became a world leader in influenza research during the Second World War, thanks to the pioneering research of the virologist Sir Frank Macfarlane Burnet (1899-1985). His clinical research unit at Melbourne Hospital searched for a flu vaccine, but when early trials failed he turned to focus on immunology and clonal selection theory, for which he was awarded a Nobel Prize in $1960 .^{30}$

Both countries experienced the post-war 'baby boom' of the 1950s and 1960s as returning servicemen married and started families. Australia's rapid population growth was also boosted by large-scale immigration from southern Europe, offering a new life for thousands of refugees displaced by the Second World War. Greeks, Italians, Yugoslavs, and displaced Jews flooded into Australian cities, giving Melbourne a cosmopolitan European character that persists to this day.

This is not the place for a detailed account of health systems as they grew and diversified in the 1960s and 1970s in response to spectacular advances in surgery, drug treatments, and hospital care. Some developments were influenced by policies of international collaboration of the World Health Organization (WHO), promoting international travel regulations and concerted immunization campaigns against infectious diseases. The spiralling cost of health care resulted in drastic restructuring from the 1980s in both Australia and New Zealand. The old Federal Department of Health in Australia was abolished in 1987 and merged with the Department of Community Services. Further additions and name changes followed during the 1990s, resulting in the Australian Federal Department of Health and Aged Care. Finally, in 2013, this was dissolved and replaced by the Federal Department of Health. ${ }^{31}$

Delivery of health care in Australia remains with the state governments. NSW Health (for New South Wales), for example, controls fifteen local health boards, which in turn administer the hospitals. Separate networks exist for children's hospitals, mental health, pathology, and ambulance services. Queensland Health has three main divisions, comprising public health, clinical practice, and health system governance. Victoria, South Australia, and Western Australia have slightly different structures but fulfil broadly the same functions.

\footnotetext{
${ }^{28}$ First New Zealand Town Planning Conference and Exhibition: Official Volume of Proceedings (Wellington: Government Printer, 1919).

${ }^{29}$ Derek A. Dow, Safeguarding the Public Health: A History of the New Zealand Department of Health (Wellington: Victoria University Press, 1995).

${ }^{30}$ Christopher Sexton, The Seeds of Time: The Life of Sir Macfarlane Burnet (New York: Oxford University Press, 1991).

${ }^{31}$ Christine C. Bennett, 'Are We There Yet? A Journey of Health Reform in Australia', Medical Journal of Australia 199, no. 4 (2013): 251-5.
} 
New Zealand's old Department of Health became the Ministry of Health in 1993, in the midst of a long period of bewildering structural changes following the adoption of neo-liberal economic policies in the 1980s. State sector reform involved functional splits between funders and providers, policy and operations, and public health and personal health services. These changes brought high levels of staff attrition and loss of institutional memory. In 2001, a population-based funding model was introduced which still prevails, and Pharmac was set up as the purchasing agency for all publicly funded medicines and supplies, including vaccines, in an attempt to make savings through bulk purchase agreements with overseas suppliers. By 2020 there were twenty district health boards under the Public Health and Disability Act, responsible for primary and secondary health care, hospitals, aged care, and disability services. District health boards also operate and employ the staff of twelve public health units (replacing district health offices), with medical officers of health coordinating a range of non-government agencies providing services. Some units serve more than one board. This complex network served the whole population regardless of race: Māori and Pacific Islanders, as well as more recent Asian migrants, were now fully integrated into the national health system. ${ }^{32}$

\section{Pandemic planning}

Australia and New Zealand were among the world's first health systems to respond to the WHO request for better pandemic planning following the SARS outbreak of 2002. Australia's health minister, Tony Abbott, announced a revised plan in 2005, and said that his chief health officer had 'warned of a possible re-run of the Spanish flu outbreak of 1919'. ${ }^{33}$ That plan was given a trial run as Exercise Cumpston in 2006, the name being an explicit reminder of the quarantine adopted in 1918. A six-month simulation was held in 2008 as Exercise Sustain, but no further exercises were held owing to cost-cutting in the health system. The Australian Pandemic History Symposium held in Canberra in May 2008 heard a paper about the 1918 flu in New Zealand and its pandemic plan.

New Zealand's first plan was soon revised after the H5N1 'bird-flu' scare, and yet again in 2005 as the National Health Emergency Plan. This was tested in 2007 in a large-scale simulation, Exercise Cruickshank, named for a female GP who had died in the 1918 flu. That year also saw the publication of ethical guidelines for a pandemic, with scenarios based on the country's experience of $1918 .^{34}$ The 2009 H1N1 outbreak in Mexico prompted yet another revision, with special reference to border controls after it was revealed that infection had arrived in New Zealand with a returning sports team from Mexico City. A revised second edition of the plan was printed in August 2017, with an explicit acknowledgement of its debt to academic historical research on the 1918 pandemic. Planning assumptions were based on the experience of $1918 .{ }^{35}$

Australia's pandemic plan was also revised after the 2009 H1N1 outbreak in Mexico, but a different approach was then adopted in its revised version in 2014, with stronger linkages to existing governance mechanisms and emergency response arrangements. There was a new emphasis on surveillance and evidence-based decision-making. This 2014 plan was reissued mostly unchanged in August 2019, with new sections on antiviral drugs, administrative amendments, and an updated literature review. ${ }^{36}$

\footnotetext{
${ }^{32}$ NNew Zealand Health System Reforms', 29 April 2009, www.parliament.nz/en/pb/research-papers/document/ 00PLSocRP09031/new-zealand-health-system-reforms.

${ }^{33}$ Sydney Morning Herald, 2 May 2005.

${ }^{34}$ National Ethics Advisory Committee, Ethical Values for Planning for and Responding to a Pandemic in New Zealand (Wellington: NEAC, 2006).

${ }^{35}$ New Zealand Influenza Pandemic Plan: A Framework for Action, 2nd edn (Wellington: Ministry of Health, 2017), www. health.govt.nz/publication/new-zealand-influenza-pandemic-plan-framework-action.

${ }^{36}$ Australian Health Management Plan for Influenza (Canberra: Australian Government, Department of Health, 2019), https://www1.health.gov.au/internet/main/publishing.nsf/Content/ohp-ahmppi.htm.
} 
Australian planning had previously been based on a worst-case scenario similar to its 1919 flu, but the 2019 plan was more flexible in its approach, scaling the response proportionately to the risk associated with the new disease. Transmissibility, clinical severity, and the capacity of the hospital system to cope with sudden heavy demand were to be key factors in the decision-making of both federal and state governments. The 1919 'Spanish' flu remained in the plan as an example of high transmissibility plus high clinical severity.

Though differing in many details, there was a broad similarity between the Australian and New Zealand plans. Australia posited four pandemic phases: prevention, preparedness, response, and recovery. The authors of the New Zealand plan adopted a more colloquial style in six phases: 'plan for it', 'keep it out', 'stamp it out', 'manage it', 'post-peak easing', and 'recover from it'. Both plans listed in exhaustive detail the enabling legislation and various government agencies to be involved at each phase. Both plans envisaged a 'whole-of-government' response, in which all ministries and agencies would provide teams of personnel trained in pandemic procedures.

This last feature of the New Zealand plan was in response to a salient lesson from the 1918 pandemic, when the capital city, Wellington, had been left leaderless for a week because a handful of key officials all came down with the flu at the same time. In the 2017 plan there were deputies for each of the key decision-makers, and groups rather than individuals tasked with coordinating the response. While individual roles were carefully defined, there was a strong emphasis on collective action and clear goals to be achieved.

In addition to planning, both Australia and New Zealand took the precaution of stockpiling antivirals, antibiotics, and personal protection equipment such as masks, gloves, and gowns. A less-publicized precaution was the stockpiling of plastic body bags, but these were also for civil defence emergencies such as floods or earthquakes. The Christchurch earthquakes of 2010 and 2011, followed by the Kaikoura earthquake of 2016, tested New Zealand's civil defence capabilities to their limits and demonstrated that careful planning had been worthwhile. ${ }^{37}$

Though delayed by bureaucratic inertia and the March 2019 mosque shootings in Christchurch, New Zealand's national memorial to New Zealanders who died in the 1918 influenza pandemic was finally unveiled by Prime Minister Jacinda Ardern in Wellington on 6 November 2019. Her speech paid tribute to the contribution of historical research to New Zealand's pandemic planning. The plaque itself referred to the pandemic as a catalyst for improvements to the New Zealand health system. Reported on national news, this event was a timely public reminder of the 1918 pandemic. ${ }^{38}$

Reminders of the 1918-19 flu occurred at regular intervals in the biennial Australian Influenza Symposia, where epidemiologists and vaccine programme directors gathered to plan for seasonal influenza. The thirteenth symposium was held in October 2019 at the Queensland University of Technology, where the centenary of Australia's 1919 flu was remembered. ${ }^{39}$ At a conference of the Influenza Specialist Group of the Immunisation Coalition held in Melbourne in February 2018, a whole day was devoted to papers on the 1918-19 pandemic in Australia, New Zealand, and the Pacific Islands. ${ }^{40}$ It is clear that pandemic planning on both sides of the Tasman Sea had been well informed by academic research on the 1918-19 influenza pandemic.

While it is axiomatic that the best-laid plans of peace and war often go astray in the face of unexpected realities, both countries could feel confident that they were well prepared for another

\footnotetext{
${ }^{37}$ Mike Ardagh and Joanne Deely, Rising from the Rubble: A Health System's Extraordinary Response to the Canterbury Earthquakes (Christchurch: Canterbury University Press, 2018).

${ }^{38}$ Martin Johnson, 'Ardern to Unveil 1918 Influenza Pandemic Plaque in Wellington', New Zealand Doctor, 22 October 2019, https://www.nzdoctor.co.nz/article/news/ardern-unveil-1918-influenza-pandemic-plaque-wellington.

${ }^{39}$ Influenza Centre, '13th Australian Influenza Symposium, 2019, Queensland University of Technology, Brisbane', http:// www.influenzacentre.org/news_symposium.htm.

${ }^{40}$ 'Reflections on the 1918 Pandemic', Influenza Specialist Group, Annual Scientific Meeting, 4-5 February 2018, Melbourne.
} 
influenza pandemic. However, the pandemic which arrived in early 2020 was not influenza but a hitherto unknown coronavirus, named COVID-19 by the WHO. It is now thought to have jumped species from bats to humans and may have been circulating in the human population before the first cluster of cases was traced to the Huanan seafood market in Wuhan City, China. Though the initial symptoms were similar to influenza, with sore throat, dry cough, and high fever, the new virus had a much longer incubation period than influenza - in some cases up to two weeks instead of the usual two to five days for influenza. It also tended to produce acute viral pneumonia rather than bacterial pneumonia. Unlike the 1918 flu, which killed mostly young adults, COVID-19 was more deadly for elderly persons with pre-existing health problems. Thus far, however, it has had a far lower case-fatality rate than its related coronavirus in the SARS outbreak of 2002. The longer incubation period would enable this highly infectious illness to spread undetected in the population, as the citizens of Wuhan City in China's Hubei province discovered as they became the epicentre of the initial outbreak in December 2019.

\section{Responses to COVID-19}

This last section will attempt to summarize briefly the experiences and responses of Australia and New Zealand. ${ }^{41}$ Australia's close trade links with China ensured that it would be an early recipient of the COVID-19 infection. Despite screening of passengers arriving from Wuhan in January 2020, the first confirmed case in Australia was a Chinese national who had flown to Melbourne. By 1 February there were ten more cases, all with links to China. Cases steadily increased, and on 27 February Prime Minister Scott Morrison activated the Australian Health Sector Emergency Response Plan. Australia's first COVID-19 death occurred on 1 March, a seventy-eight-year-old who had been a passenger on the cruise ship Diamond Princess in Yokohama. He had been evacuated and treated in Western Australia.

Community transmission was first confirmed on 2 March, and the first COVID-19 case was reported from Tasmania. By 12 March there were 142 confirmed cases. Panic-buying of food and toilet paper was widely reported in March as people prepared for a possible emergency. On 15 March all incoming travellers were required to self-isolate for fourteen days. New South Wales banned all gatherings over 500 on 16 March, and other states soon adopted similar restrictions. Australia declared a human biosecurity emergency on 18 March, under section 475 of the 2015 Biosecurity Act. Two days later the borders were closed to all non-residents and non-citizens. Another cruise ship, the Ruby Princess, had arrived in Sydney with COVID-19 cases on 19 March, and passengers were sent into self-isolation. The final total from this ship was 440 cases with five deaths. Several more cruise ships returning to Australian ports contributed further cases and a few more deaths. On 25 March a National COVID-19 Coordination Commission was set up to give strategic advice to the national response team. All state governments were now on full alert and advising elderly people to stay at home.

Australia adopted a partial shutdown in response to COVID-19. Schools remained open, but from 22 March all places of social gathering such as churches, clubs, pubs, bars, casinos, gyms, libraries, and playgrounds were closed. Cafés and restaurants were closed but allowed to offer takeaway services. Essential businesses and services continued to operate normally. Universities cancelled graduation ceremonies and moved to online teaching where possible. Social distancing was recommended in the form of a 'four square metres' rule per person. However, the sight of crowds at Bondi Beach on 20 March aroused public anger, and police were called to disperse them. The beach was later closed. School holidays were then brought forward and parents were encouraged to keep children at home and avoid social contact.

\footnotetext{
${ }^{41}$ In order to avoid excessive footnoting, this last section is largely based on these websites: https://en.wikipedia.org/wiki/ COVID-19_pandemic_in_New_Zealand; https://en.wikipedia.org/wiki/COVID-19_pandemic_in_Australia.
} 
The government moved to soften the economic impact of COVID-19 with an AU\$17.6 billion stimulus package on 12 March, and again on 30 March with an AU\$130 billion 'Job-keeper' wage subsidy. By this time, over a million Australians were out of work thanks to COVID-19. However, testing for the virus was finding fewer new cases. New South Wales had conducted 180,000 tests by 23 March, with Victoria and Queensland at about 90,000 each. The national total by then was 466,659 . Health officials were confident that testing was finding $93 \%$ of all cases.

Australians had nicknamed the new virus 'Rona' and were on the whole following advice about social distancing and personal hygiene such as hand-washing. By 6 April the Health Department was able to announce that 2,432 had recovered from 5,687 cases. There were sixteen 'clusters' of related cases and deaths across Australia, from social events, schools, or aged care facilities. But the reproduction rate was encouragingly low, 0.4 for Queensland and 0.3 for New South Wales, South Australia, and Western Australia. Any figure below 1 suggested that the virus would in time die out.

By 21 April new cases had dwindled to single figures in all Australian states, and it was clear that this first phase of the COVID-19 pandemic had passed its peak. There was even talk of reopening the trans-Tasman border with New Zealand. But the rest of the world was in a sorrier state, with 2.6 million cases and 184,000 deaths. By 21 May Australia had recorded 100 deaths from COVID-19, at a rate of 4 per million of population, and a case-fatality rate of 14.1 per thousand.

New Zealand's response to the COVID-19 virus was on the whole swifter and stricter than that of Australia. While following similar steps, New Zealand was usually a day or more ahead of Australia. Long before there were any COVID-19 cases in the country, on 28 January 2020 the government set up a National Health Coordination Centre to monitor the outbreak, and issued an Infectious and Notifiable Diseases Order two days later. New Zealanders returning from China were quarantined for fourteen days at a military facility. New Zealand progressively closed its borders from 3 February and confirmed its first COVID-19 case on 28 February. Large public gatherings were banned from 16 March and travellers returning to New Zealand were asked to self-isolate for fourteen days. On 19 March retired medical staff were invited to assist in hospitals and medical centres.

Like Australia, the New Zealand government moved to soften the economic damage from a prolonged lockdown with a NZ\$12 billion business support package. This included NZ\$8.7 billion for businesses, NZ\$2.8 for income support, NZ\$500 million for health service, and NZ\$600 million for aviation supply chains. On 22 March, NZ\$56.4 million was allocated to support Māori communities. The lockdown caught thousands of foreign tourists by surprise, and their governments in some cases chartered special evacuation flights to help them leave New Zealand.

In mid March, after modelling predicted up to 14,000 deaths if no further measures were adopted, the strategy was changed from 'suppression' to 'elimination' of the COVID-19 virus. The government had decided to 'go early and go hard' with stricter measures. On $21 \mathrm{March}$, the prime minister announced a four-level emergency alert system and set the level at 2 , requiring persons over seventy to stay at home. Two days later the alert level was raised to 3 and schools were closed. On 25 March a national state of emergency was declared and alert Level 4 was imposed. The country started a four-week lockdown, with all non-essential businesses and services closed.

New Zealand news media were quick to make comparisons between COVID-19 and the 1918 influenza pandemic. Newspaper articles with titles such as 'Lessons from Black November' and 'Remembering the Spanish Influenza' began to appear during March. ${ }^{42}$ The Pākehā population was reminded that Māori had good reason to be worried about COVID-19, given their painful

\footnotetext{
${ }^{42}$ 'Lessons from Black November', Press (Christchurch), 19 March 2020; Geoffrey Rice, 'Coronavirus: Is NZ Facing a Repeat of the 1918 Flu Pandemic?', Noted, 3 March 2020, https://www.noted.co.nz/health/health-health/coronavirus-nz-are-wefacing-a-repeat-of-1918-flu-pandemic; Kirsty Johnson, 'Coronavirus: Lessons Learned from the Great Influenza Pandemic
} 
losses in $1918 .^{43}$ In early April an editorial in the New Zealand Medical Journal wondered if the COVID-19 pandemic would be remembered as 'the exit of the elderly' or 'the pensioners' plague', since most deaths so far had been of frail elderly persons. ${ }^{44}$

Leadership and communication had been weak elements in New Zealand's initial response to the $1918 \mathrm{flu}$, but that lesson had been learned, and a feature of New Zealand's COVID-19 response was the prime minister's daily 1 p.m. TV briefing to the nation, accompanied by the DirectorGeneral of Health, Dr Ashley Bloomfield (himself a public health specialist). Their open, honest, and realistic reports fostered a high level of public trust. Most notably, Ardern urged New Zealanders to be kind to one another through this difficult time.

Unlike 1918, when the Minister of Health assumed a leadership role, in 2020 the Minister of Health became almost invisible after being found to have twice breached his own COVID-19 travel restrictions. Instead the Director-General of Health exercised his authority as the national medical officer of health, offering clear and expert national leadership. In 1918, Parliament had provided the customary constitutional checks of the legislative branch over the executive, whereas in 2020 a new Epidemic Response Committee chaired by the Leader of the Opposition called ministers and officials to account for their actions.

New Zealand's first death from COVID-19 occurred on 29 March, when confirmed cases had reached 514. By 23 April these figures had increased to sixteen deaths and 1,451 cases, of whom 1,065 had recovered, with sixteen 'clusters' identified and isolated. Testing and tracing had rapidly increased to over 6,000 a day, matching that of Australia at a rate of about 14,000 per million of population. Nearly all of the 100,000 tests returned negative results. New cases peaked on 5 April at eighty-nine, then declined steadily to reach single figures by 17 April. Nearly all cases had links to overseas travel, and community transmission was at a very low $2 \%$. New Zealand had effectively 'flattened the curve', but the government agreed on expert epidemiological advice to extend the Level 4 lockdown for another five days, to include ANZAC Day, and move down to Level 3 on 27 April for a further two weeks. A survey held on 20-21 April found a high level of satisfaction with the government's handling of the crisis, at $87 \%$, with only $8 \%$ not satisfied. Some people are never satisfied.

At the time of writing, New Zealand's pandemic curve has been flattened to zero and there have been no new cases for twenty consecutive days, bringing the country close to its aim of eliminating the COVID-19 virus. With only 22 deaths from 1,504 cases New Zealand's strict lockdown measures have worked well. Australia has had 7,285 cases and 102 deaths, and still has several hundred recovering cases. Both countries have recorded a death rate of 4 per million. This places them in a group of fortunate countries that includes China, Taiwan, Singapore, Malaysia, South Korea, and Japan with very low death rates. By contrast, the US has passed 2 million cases with 115,787 deaths. The UK now leads European countries with over 40,000 deaths, and cases have surged in Brazil, Russia, Mexico, and India.

New Zealand's decision, based on the experience of 1918, to 'go early and go hard' appears to have worked well. (Yet Australia and Japan have seen similar results with looser restrictions than New Zealand.) Seasonality may have had an influence on transmission of coronavirus, as southern hemisphere countries in late summer have all done much better than Europe and North America in late winter and early spring. The economic impact of COVID-19 is expected to be severe. Both the Australian and New Zealand governments have borrowed heavily from their central banks to finance their COVID-19 responses. It also remains to be seen how much the COVID-19 virus may change as it passes through large human populations, and while it seems to be a more stable virus

\footnotetext{
of 1918', New Zealand Herald (Auckland), 18 March 2020, https://www.nzherald.co.nz/nz/news/article.cfm?c_id= 1\&objectid=12317506.

${ }^{43}$ Delilah Whaitiri, 'Lessons from the Graves of Our Tupuna', Whakatane Beacon, 6 April 2020.

${ }^{44}$ Geoffrey Rice, 'Here We Go Again? A New Pandemic of the 21st Century', New Zealand Medical Journal 133, no. 1512 (2020): 8-9.
} 
than influenza it might yet develop a more severe strain, as A/H1N1 did in 1918, and return in a second wave. Until an effective vaccine can be produced for COVID-19, the world may have to endure a prolonged smouldering pandemic, with further flare-ups and outbreaks for another year or more. As New Zealand's prime minister has observed, this looks more like a marathon than a sprint.

Dr Geoffrey W. Rice FRHistS lectured in European history at the University of Canterbury, New Zealand, from 1973, ending as Professor and Head of Department (2006-12). He edited the second edition of the Oxford History of New Zealand (1992). His pioneering book Black November (1988, 2nd edn 2005) was the first modern study of the 1918 influenza pandemic based on individual death records for a whole country. He has published numerous articles and ten local histories and biographies with Canterbury University Press, as well as Black Flu 1918: The Story of New Zealand's Worst Public Health Disaster (2017). $\mathrm{He}$ is currently working on medical men and public health in nineteenth-century New Zealand.

Cite this article: Rice G.W. 2020. How reminders of the 1918-19 pandemic helped Australia and New Zealand respond to COVID-19. Journal of Global History 15: 421-433, doi:10.1017/S1740022820000285 